\title{
BEHAVIORAL ACTIVATION (BA) UNTUK MENURUNKAN GANGGUAN DEPRESI PADA MAHASISWA UNIVERSITAS NEGERI JAKARTA
}

\author{
Ernita Zakiah* \\ *Universitas Negeri Jakarta
}

DOI: https://doi.org/10.21009/JPPP.082.07

\author{
Alamat Korespondensi: \\ ernitazakiah@unj.ac.id
}

\begin{abstract}
This study aims to examine the effect of Behavioral Activation (BA) to reduce student's depression disorders of Universitas Negeri Jakarta. Methods of data collection using observations, semi-structured interviews, and BDI measurement tools. The measuring instrument used is the Beck Depression Inventory (BDI) made by Beck in (1976) translated by Zarina (2007). Interference disorders need to be given an intervention, because subjects with depressive disorders tend to avoid social environment, easily feel tired, avoid or do nothing activities, almost all the time experiencing feelings of depression, easily distracted concentration, etc.
\end{abstract}

Keywords

Behavioral activation (BA), depression.

\section{Pendahuluan}

Manusia dalam menjalani kehidupan, banyak mengalami situasi yang menyenangkan ataupun tidak menyenangkan. Individu yang mengalami situasi yang menyenangkan merasakan dampak yang positif, begitu juga sebaliknya individu yang mengalami atau menghadapi situasi yang tidak menyenangkan merasakan dampak yang negatif, meskipun ada sebagian individu yang mendapatkan dampak yang positif dari pengalaman atau situasi yang tidak menyenangkan. Situasi atau pengalaman yang tidak menyenangkan sering membuat individu mengalami kesulitan untuk mengatasinya, karena tidak punya cara atau pengetahuan untuk mengatasi dampak yang mereka rasakan. Jika individu tidak mampu mengatasinya, hal ini yang sering membuat individu mengalami berbagai gejala atau simtom yang mengarah pada gangguan psikologis.

Kondisi seperti ini juga dialami oleh mahasiswa, banyak diantara mereka yang datang ke biro psikologi ataupun ke psikolog untuk mendapatkan penanganan. Dari beberapa kasus yang ditemukan dilapangan, faktor penyebab mereka mengalami permasalahan psikologis karena pengalaman mereka yang tidak menyenangkan, seperti kegagalan menghadapi ujian, tuntutan orangtua, mendapatkan bullying dari teman-teman, putus hubungan dengan pacar, dan lain-lain. Ada berbagai macam permasalahan psikologis yang dialami oleh mahasiswa, seperi kecemasan, gangguan mood, PTSD, depresi, dll.

Thurai \& Westa (2017) menjelaskan bahwa banyak masalah psikologis yang dialami oleh mahasiswa seperti kecemasan, somatoform, gangguan mood, dan lain-lain, namun masalah psikologis yang paling umum dialami oleh mahasiswa adalah depresi.

Martell et al., (2010) menjelaskan bahwa intervensi psikologis dengan teknik behavioral activation (BA) efektif untuk menangani gangguan depresi maupun gangguan lainnya. Behavioral activation (BA) sudah banyak dilakukan untuk menangani gangguan depresi, diantaranya yang ditunjukkan dari hasiil penelitian yang dilakukan 
oleh oleh Manos et al., (2010) bahwa behavioral activation (BA) efektif untuk menurunkan gangguan depresi. Selain untuk menangani gangguan depresi, behavioral activation (BA) juga efektif untuk menurunkan gangguan PTSD hal ini ditunjukkan dari hasil penelitian yang dilakukan oleh Wagner et al., (2007) yang melakukan penelitian dengan penyintas gangguan stres pasca trauma dan depresi yang mengalami cedera fisik.

Penelitian lain yang dilakukan oleh Mulick \& Naugle (2009) tentang efektifitas behavioral activation (BA) untuk menangani gangguan stres pasca trauma comorbid dengan depresi. Keefektifan behavioral activation (BA) juga di temukan pada hasil penelitian yang dilakukan oleh Turner \& Jakupcak (2010) yang digunakan untuk menangani gangguan stres pasca trauma, depresi dan gangguan nyeri. Jayati \& Hadjam (2015) menemukan bahwa behavioral activation (BA) efektif untuk menurunkan tingkat depresi pada pasien stroke.

Martell et al., (2010) menjelaskan bahwa teknik behavioral activation (BA) dilakukan dengan memiliki tujuan pokok yaitu meningkatkan kegiatan dan keterlibatan individu dalam kehidupan, behavioral activation (BA) juga berfokus pada proses yang mencegah aktivitas negatif, seperti perilaku melarikan diri dan penghindaran. Kanter, Manos, Busch \& Rusch (2008) menjelaskan bahwa behavioral activation (BA) menekankan pada aktivitas dan strategi pelatihan keterampilan untuk meningkatkan kontak dengan penguatan positif.

Martell et al., (2010) menjelaskan bahwa penjadwalan peristiwa menyenangkan atau memuaskan (seperti pada tahap pertama terapi kognitif) pada teknik behavioral activation (BA) fokusnya adalah pada seluruh peristiwa dan variabel yang dapat memengaruhi terjadinya tanggapan tidak baik dari perilaku dan proses kognitif, secara kontekstualisasi menghindari dan menarik diri dari aktivitas dan interaksi sosial.

Intervensi dengan behavioral activation (BA) juga menggiatkan subjek untuk melakukan kegiatan, sehingga waktu luang yang sebelumnya diisi dengan memikirkan pengalamannya digunakan untuk melakukan kegiatan. Dengan behavioral activation (BA) subjek bereksperimen melakukan kegiatan yang sudah tidak dilakukan atau melakukan aktivitas baru, sehingga subjek merasa lebih percaya diri karena mampu melakukan aktivitas yang selama ini dihindari dan efeknya adalah merasa senang karena ada perbaikan dalam hidup.

Berdasarkan pemaparan di atas, peneliti tertarik untuk melihat keefektifan behavioral activation (BA) untuk menurunkan gangguan depresi pada mahasiswa Universitas Negeri Jakarta.

\section{Metode Penelitian}

Penelitian ini menggunakan desain eksperimen (one group pre and posttest design) metode ini merupakan desain eksperimen yang hanya menggunakan satu kelompok subjek (kasus tunggal) serta melakukan pengukuran sebelum dan sesudah pemberian perlakuan kepada subjek. Perbedaan kedua hasil pengukuran tersebut dianggap sebagai efek perlakuan (Latipun, 2006).

Penelitian ini memberikan satu perlakuan kepada satu kelompok subjek dengan melakukan dua kali pengukuran yaitu pre-test yaitu pengukuran yang dilakukan sebelum memberikan perlakuan, post-test yaitu pengukuran yang dilakukan setelah perlakuan diberikan.

Populasi subjek penelitian ini adalah semua mahasiswa Universitas Negeri Jakarta yang mengalami gangguan depresi. Subjek penelitian ini adalah sebagian mahasiswa Universitas Negeri Jakarta yang mengalami gangguan depresi yang sesui dengan kriteria sampel penelitian.

Metode pengumpulan data dengan menggunakan observasi, wawancara dan pengukuran dengan menggunakan instrument untuk mengungkap depresi dalam penelitian ini adalah angket depresi yang diadapatasi dari Beck Depression Inventory (BDI). Alat ukur yang digunakan yaitu Beck Depression Inventory (BDI) dibuat oleh Beck pada (1976). Alat ukur ini sudah diterjemahkan oleh Zarina pada tahun 2007. Teknik analisis data yang digunakan dalam penelitian ini adalah dengan melihat perbedaan skor pre-test dan post-test. Selain itu juga dilakukan analisis secara kualitatif.

\section{Hasil Penelitian dan Diskusi}

Pertemuan pertama dilakukan konseling dengan beberapa mahasiswa untuk melakukan screening subjek penelitian. Metode yang dilakukan adalah dengan konseling terkait hambatan atau simtom yang dialami oleh subjek. Pertemuan pertama selain melakukan konseling juga meminta secara verbal kesediaan mahasiswa untuk menjadi subjek penelitian. Selain itu, peneliti juga mengajukan ketersediaan subjek untuk mengikuti sesi terapi yang akan dilakukan oleh psikolog lain, 
bukan peneliti yang akan melaksanakan terapi dalam penelitian.

Dari hasil konseling ditemukan beberapa gejala atau simtom yang dialami subjek: subjek SC merasa pesimis terhadap masa depan karena merasa tidak yakin dengan kemampuan diri untuk mencapai tujuan atau harapannya di masa depan. Selain itu, subjek juga merasa tidak berharga dan orang yang gagal, karena belum mampu menyelesaikan kuliahnya dan belum mampu membahagiakan orangtuanya. Subjek juga sering merasa sedih tanpa sebab dan ini muncul hampir di sepanjang waktu, karena sering membandingkan dirinya dengan orang lain, subjek menilai hidupnya tidak bahagia dan menilai hidup orang lain lebih bahagia. Hal ini, yang membuatnya menarik diri dari lingkungan sosial dan banyak menghabiskan waktu termenung, sehingga banyak mengabaikan pekerjaan lain karena merasa mudah lelah saat mengerjakan satu pekerjaan.

Pertemuan kedua diawali dengan perkenalan kembali antara subjek dengan fasilitator dan membangun rapport kembali. Setelah itu cofasilitator memberikan lembar informed consent untuk ditandatangani subjek sebagai bukti persetujuan untuk mengikuti sesi terapi dari awal sampai akhir. Sesi selanjutnya adalah pre-test dengan meminta subjek untuk mengisi lembar BDI sesuai dengan kondisi yang dialami subjek.

SC mengalami beberapa simtom seperti memiliki pandangan negatif tentang diri dan hidunya, hal ini ditunjukkan dengan sering membandingkan dirinya dengan orang lain, hal ini tampak saat subjek menilai hidupnya tidak bahagia dan penuh permasalahan dibandingkan dengan teman-temannya yang dinilai lebih bahagia. Kondisi ini juga yang membuatnya menghindari lingkungan sosial, karena merasa tidak memiliki hal yang dibanggakan dari dirinya.

Subjek SC juga sering merasa sedih, seperti sering menangis tanpa sebab apapun, sering merasa sedih saat memikirkan kondisinya saat sekarang, sehingga ini yang membuatnya merasa tidak nyaman. Subjek juga menyampaikan sulit untuk merasa bahagia, sehingga banyak aktivitas yang tidak lakukan yang sebelumnya dilakukan, subjek merasa dia mudah merasa lelah saat melakukan aktivitas dan sering termenung karena memikirkan permasalahan yang dialaminya.

Pertemuan ketiga, subjek diberikan psikoedukasi tentang hubungan antara pikiran terhadap perasaan dan perilaku, serta menjelaskan lingkaran permasalahan dan lingkaran aktivasi. Saat materi disampaikan, subjek tampak antusias yang ditunjukkan dengan aktif bertanya tentang materi yang diberikan dan menceritakan pengalaman yang dialaminya. Subjek SC yang menilai negatif pada dirinya, dengan sering membandingnya dirinya dengan orang, ia menilai hidupnya lebih menderita dibandingkan orang lain, sehingga membuatnya minder diantara teman-temannya. Subjek juga memiliki pandangan negatif tentang lingkungan, ia menilai teman-temannya adalah orang yang banyak menghabiskan waktu untuk bersenang-senang, sehingga ia merasa tidak layak, hal inilah yang membuatnya menarik diri dari lingkungan sosial.

Pertemuan keempat dimulai dengan salam dan membangun hubungan yang baik dengan subjek penelitian. Kegiatan selanjutnya adalah melakukan identifikasi penyebab munculnya permasalahan, SC sering merasa sedih, marah dan pesimis terhadap masa depan, karena merasa tidak memiliki kemampuan yang layak untuk digunakan di masa depan. SC merasa tidak nyaman dengan kondisi yang alami, karena berpengaruh terhadap kesehatannya misalnya sering mengalami keluhan fisik seperti pusing, migren, dan punggung sering terasa sakit. Gejala lain yang diasakan subjek adalah kurangnya minat melakukan aktivitas, karena kurang mampu menikmati aktivitas yang dilakukan, ia lebih banyak menghabiskan banyak waktu termenung atau memikirkan permasalahannya.

Sesi selanjutnya adalah pelaksanaan relaksasi, subjek SC tidak mengalami kesulitan untuk mengkuti instruksi. SC juga merasa nyaman saat melakukan relaksasi, namun subjek menyampaikan ada pengalaman yang tidak menyenangkan di masa lalu yang selama ini diabaikan muncul saat sesi relaksasi.

Pertemuan kelima dimulai dengan mendiskusikan efek yang dirasakan setelah mengikuti relaksasi di pertemuan sebelumnya. SC menyampaikan ia merasa nyaman di bagian pundaknya, seperti ada beban yang selama ini terasa berat kini berkurang. Selain itu ia juga merasa tidurnya lebih nyenyak dan lebih tenang. Meskipun, saat di rumah subjek menyampaikan ada masalah dengan suami, namun ia mampu mengontrol rasa marahnya untuk tidak dilampiaskan kepada anaknya. Saat ditanyakan emosi atau perasaan yang dirasakan SC tidak kesulitan untuk menyampaikan emosi yang dirasakan.

Kegiatan selanjutnya fasilitator mengajak subjek 
untuk mengidentifikasi makna hidup subjek terkait beberapa aspek dan cara untuk mencapainya. Kemudian fasilitator mengajak subjek untuk mendiskusikan kegiatan yang akan dilakukan pada beberapa hari kedepan untuk mewujudkan makna hidup yang telah dituliskan, dengan memberikan contoh cara pengisian lembar aktivasi terlebih dahulu. Selanjutnya diminta untuk mengisi kolom kapan akan dilakukan dan kemungkinan kendala yang akan ditemukan dalam melakukan rencana kegiatan. Saat pengisian lembar aktivasi yang digunakan sebagai contoh SC tampak ragu-ragu menuliskan kegiatan yang akan dilakukan, karena tidak yakin akan mampu melakukannya.

Sesi selanjutnya adalah latihan relaksasi, SC tidak mengalami kesulitan untuk mengikuti instruksi. Ia juga menyampaikan bahwa masalah lain yang berbeda dari latihan relaksasi sebelumnya juga muncul, hal ini berkaitan konflik dengan teman, masalah yang tidak ia sadari selama ini juga muncul di sesi relaksasi pertemuan ini. Namun subjek menyampaikan bahwa ia merasa bahwa pengalaman-pengalaman yang selama ini tanpa disadari memberikan dampak pada dirinya saat ini, Ia menyadari bahwa ia harus menyelesaikan konflik dengan temannya, agar ia merasa lebih nyaman.

Pertemuan keenam telebih dahulu fasilitator mengajak subjek membahas tugas rumah yang telah dikerjakan, seperti mengidentifikasi efek yang rasakan selama mengikuti kegiatan. Efek yang dirasakan oleh SC adalah kegiatan lebih tertata, sehingga kegiatan yang selama ini sudah tidak dilakukan, sekarang kembali dilakukan dan berhasil. Hal ini yang membuatnya ingin melanjutkan kembali aktivas tersebut di waktu selanjutnya, meskipun ada aktivitas yang tidak terlaksana subjek tetap ingin melaksanakannya setelah pertemuan selesai. SC juga merasa lebih mampu mengontrol emosi, sehingga hubungan dengan suami dan anak menjadi lebih baik, hal ini membuat subjek merasa bahagia.
Sesi selanjutnya adalah latihan relaksasi, subjek tidak mengalami hambatan untuk mengikuti instruksi yang dibacakan. SC mampu mengikuti instruksi dan merasa lebih tenang dan lega, meskipun subjek menjelaskan bahwa pengalamannya yang tidak menyenangkan yang pernah dialaminya yang tidak muncul saat sesi konseling maupun pertemuan sebelumnya muncul dalam pertemuan ini. Pengalaman yang muncul pada pertemuan ini yaitu hubungan yang kurang harmonis dengan adik perempuannya.

Pertemuan ketujuh diawali dengan menanyakan kondisi subjek, kemudian melakukan monitoring kegiatan atau aktivitas yang sudah dikerjakan oleh subjek. SC menyampaikan ada beberapa tugas yang tidak berhasil dilakukan, karena ada hambatan harus menemani suami dan sibuk mempersiapkan perayaan ulang tahun anaknya, namun ia lebih banyak berhasil melakukan aktivitas yang sudah direncanakan. Subjek menyampaikan bahwa target kegiatan yang sudah direncanakan benar-benar diusahan untuk dikerjakan sesuai yang sudah ditargetkan, meskipun ada kendala saat mengerjakan kegiatan atau aktivitas. Subjek merasakan perubahan perasaan setelah behasil melakukan kegiatan diantaranya merasa puas, bangga pada diri, senang dan lebih percaya diri.

Subjek SC juga merasakan perubahan, bahwa keluhan fisiknya sekarang sudah tidak pernah muncul lagi dan tidurnya sudah lebih nyenyak. Subjek juga merasa jauh lebih sering merasakan emosi positif, dibandingkan sebelum mendapatkan intervensi. Selain itu, SC merasa lebih disiplin dalam menjalankan kegiatan, sehingga lebih tertata dibandingkan sebelumnya.

Pertemuan kedelapan yaitu pelaksanaan terminasi dan melakukan pengukuran setelah melakukan intervensi. Adapun hasil pengukuran pre-test dan post-test BDI subjek yang ditunjukkan pada grafik dibawah ini.

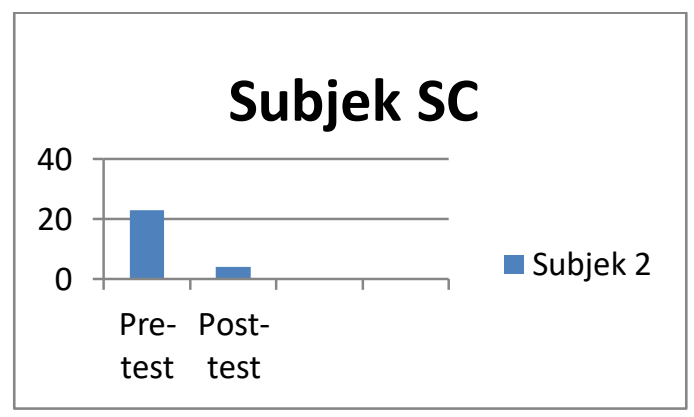




\section{Kesimpulan}

Berdasarkan hasil penelitian ini dapat disimpulkan bahwa terdapat pengaruh behavioral activation (BA) untuk menurunkan gangguan depresi pada mahasiswa Universitas Negeri Jakarta. Subjek penelitian mengalami penurunan skor BDI pada pengukuran sebelum diberikan intervensi (pre-test) dengan skor BDI setelah diberikan intervensi (post-test). Hal ini membuktikan bahwa behavioral activation (BA) efektif untuk menurunkan gangguan depresi pada mahasiswa Universitas Negeri Jakarta.

\section{Daftar Pustaka}

Beck, A. T., Rush, A. J., Shaw, B. F., \& Emery, G. (1979). Cognitive therapy of depression. New York: The Guilford Press.

Jayati, I.S \& Hadjam, M.N.R. (2015). Tata laksana 'behavioral activation' untuk menurunkan tingkat depresi pada pasien stroke. Journal of Propessional Psychology. 1(2), 77-88.

Kanter, J.W., Andrew, M.B \& Laura, C.R. (2008). Making behavioral activation more behavioral. Behavioral Modification, 20(10), $1-24$.

Kanter, J.W., Andrew, M.B \& Laura, C.R. (2009). Behavioral activation. Routledge.

Latipun. (2006). Psikologi Eksperimen. Malang: Universitas Muhammadiyah Malang.

Martell, dkk. (2010). The development of behavioral activation. Guilford.

Martell, C.R., Soha, D \& Ruth, H.D. (2010). Behavioral activation for depression. New York: The Guilford Press.

Manos, R.C., Jonathan, W.K \& Andrew, M.B. (2010). A critical review of assessment strategies to measure the behavioral activation model of depression. Clinical Psychology Review, 30, 547-561.

Maslim, R. (2001). Diagnosisi gangguan jiwa. Jakarta
Mulick, P.S., Landes, J.S \& Kanter, W.J. (2009). Contextual Behavior Therapies in the Treatment of PTSD: A Review. The International Journal of Behavioral Consultation and Therapy, 7(1), 23-31.

Nevid, J.S., Spencer, A.R \& Beverly, G. (2005). Psikologi abnormal (ed. Ke-5). Jakarta. Penerbit Erlangga.

Soraya. (2014). Uji validitas konstruk beck depression inventory-II (BDI-II). UIN Syarif Hidayatullah. Jakarta.

Sugiyono. 2011. Metode Penelitian Kuantitatif, Kualitatif dan R\&D. Bandung: Afabeta.

Thurai, R.S.T \& Westa, W. (2017). Tingkat depresi dalam kalangan mahasiswa kedokteran semester VII Universitas Udayana dan keterlibatan mereka dalam kegiatan fisik, DOAJ, 8(2), 147-150.

Tuner, P.A \& Jakupcak, M. (2010). Behavioral activation for treatment of ptsd and depression in an iraqi combat veteran with multiple physical injuries. Behavioral and Cognitive Psychoterapy, 38, 355-361.

Wagner, W.A. Zatzick, F.D., Ghesquiere, A and Jurkovich, J.G. (2007). Behavioral activation as an early intervention for posttraumatic stress disorder and depression among physically injured trauma survivors. Cognitive and Behavioral Practice, 14, 341-349.

Zakiah, E. (2017). Behavioral activation (BA) untuk menurunkan gangguan stres pasca trauma pada korban tanah longsor di kabupaten Banjarnegar. Tesis. Universitas Ahmad Dahlan.

Zarina, Akbar. (2007). Efektivitas Pelatihan Manajemen Emosi Sebagai Program Pemulihan Untuk Mengatasi Depresi Pada Remaja Korban Gempa Bumi Yogyakarta. Tesis. Universitas Gadjah Mada. 